Sari Pediatri, Vol. 7, No. 2, September 2005: 63 - 67

\title{
Stress Oksidatif pada Autisme
}

\author{
Ruslan*, Eko Suhartono**
}

Latar belakang: autisme merupakan gangguan perkembangan berat dalam hal berkomunikasi, interaksi sosial, dan perilaku yang tampak sebelum anak berusia 3 tahun. Gangguan perkembangan ini dihubungkan dengan faktor psikologi, kelainan neurobiologi, genetik, gangguan metabolik, pencernaan, keracunan logam berat dan biokimia.

Tujuan: mengetahui kelainan biokimia yaitu senyawa oksigen reaktif (SOR) dan nitrogen oksida (NO) pada autisme. Peningkatan SOR dan NO diduga menyebabkan stres oksidatif yang berperan dalam neuropatologi pada autisme.

Metoda: penelitian terhadap 39 anak autisme sebagai kelompok risiko dan 10 anak normal sebagai kontrol, melalui studi observasional analitik dengan metode crosssectional. Akumulasi SOR ditentukan dengan mengukur aktivitas katalase dan kadar senyawa karbonil secara spektrofotometrik. Aktivitas NO ditentukan secara tidak langsung, yakni mengukur kadar methemoglobin dalam plasma.

Hasil: rerata aktifitas katalase pada autisme $0,0061 \pm 0,0013 \mathrm{~s}^{-1}$, sedangkan kontrol adalah $0,0086 \pm 0,0042 \mathrm{~s}^{-1}$. Rerata hasil pengukuran methemoglobin pada autisme adalah $30,38 \pm 15,44 \%$ sedangkan kelompok kontrol $21,73 \pm 9,66 \%$. Kadar senyawa karbonil pada autisme adalah $0,411 \pm 337693 \mathrm{iM} \mathrm{ml}^{-1} / \mathrm{gr}$ dan kontrol $0,424 \pm 265861 \mathrm{iM} \mathrm{ml} \mathrm{ml}^{-1} / \mathrm{gr}$. Uji-t untuk dua rata-rata pada $a=5 \%$ menyimpulkan aktivitas katalase dan kadar methemoglobin berbeda secara bermakna dibandingkan kontrol $(\mathrm{P}<0,05)$, sedangkan kadar senyawa karbonil kelompok risiko dan kontrol tidak berbeda $(P>0,05)$

Kesimpulan: aktivitas katalase pada anak autisme lebih rendah dan kadar methemoglobin lebih tinggi secara bermakna dibandingkan anak normal. Meskipun demikian, keadaan tersebut belum sampai mempengaruhi kerusakan oksidatif protein. Perlu dilakukan penelitian lebih lanjut untuk mengetahui aktivitas antioksidan endogen lainnya seperti superoksida dismutase dan glutation peroksidase serta apakah kadar senyawa antioksidan berhubungan dengan derajat gejala klinis anak autisme.

Kata kunci: autisme, senyawa oksigen reaktif (SOR), nitrogen oksid (NO), aktifitas katalase, kadar methemoglobin, senyawa karbonil.

\footnotetext{
Alamat Korespondensi:

Dr. Ruslan, Sp.A

Bagian Ilmu Kesehatan Anak RSUD Ulin/Fak. Kedokteran Universitas lambung Mangkurat, Banjarmasin.

Telp/Fax. (0511)269177, E-mail: idai_kalsel@yahoo.com

*Bagian Ilmu Kesehatan Anak RSUD Ulin/Fak. Kedokteran Universitas Lambung Mangkurat, Banjarmasin.

** Bagian Kimia Kedokteran Fak. Kedokteran Universitas Lambung Mangkurat, Banjarmasin.
}

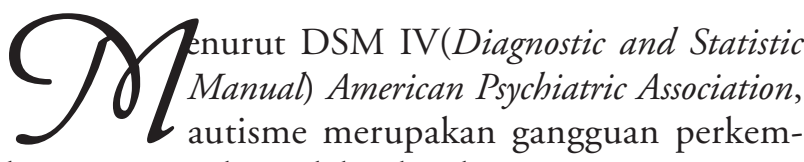
bangan yang kompleks dan berat. Gangguan perkembangan ini selanjutnya dapat mempengaruhi cara berkomunikasi, interaksi sosial, dan perilaku pada anak autisme. ${ }^{1,2}$ Gejala autisme ini, sering muncul sebelum anak berusia 3 tahun. Sejauh ini, penyebab autisme 
belum dapat dipastikan, namun beberapa teori mengaitkan autisme dengan kelainan genetik, saluran cerna, metabolik, imunologik, keracunan logam berat, neurobiologi, dan biokimia. ${ }^{3-7}$ Salah satu penyebab kelainan biokimia, yaitu peningkatan senyawa oksigen reaktif (SOR) dan nitrit oksida (NO) diduga terlibat dalam patofisiologi autisme. . $^{4,6}$

Senyawa oksigen reaktif (SOR) adalah metabolit oksigen utama yang dihasilkan melalui reduksi satu elektron oksigen dari hasil metabolisme dan reaksi kimia dalam tubuh. ${ }^{7}$ Senyawa oksigen reaktif (SOR) mencakup radikal anion superoksida $\left(\mathrm{O}_{2}^{-}\right)$dan radikal hidroksil $(\mathrm{OH})$. Selain itu, terdapat turunan $\mathrm{O}_{2}$ yang bukan radikal yaitu hidrogen peroksida $\left(\mathrm{H}_{2} \mathrm{O}_{2}\right)$ dan singlet oksigen $\left(\mathrm{O}_{2}\right) .{ }^{8,9}$

Hampir semua SOR bersifat reaktif. Reaktifitas SOR tersebut dapat menyebabkan kerusakan strukrur molekul penyusun membran sel. Senyawa SOR dengan lipid akan menyebabkan peroksidasi lipid, yang menghasilkan malondialdehid (MDA) dan 4hidroksialkenal yang bersifat toksik. Selain itu SOR juga dapat mengoksidasi struktur protein dan membentuk senyawa karbonil. ${ }^{10}$ Untuk menghambat kerusakan tersebut, tubuh mempunyai sistem pertahanan antioksidan endogen berupa enzim dan molekul dengan bobot rendah. Contoh antioksidan berupa enzim, yaitu katalase, glutation peroksidase, dan superoksida dismutase. Bentuk lain adalah antioksidan bobot molekul rendah misalnya bilirubin, asam urat, laktoferin, dan lain-lain. ${ }^{10}$

Selain SOR, senyawa nitrogen reaktif (SNR) juga dapat menyebabkan stress oksidatif, misalnya nitrit oksid (NO). Nitrit oksid disintesis dari asam amino arginin melalui nitrogen oksida sintase (NOS). Nitrit oksid merupakan senyawa kimia berfungsi sebagai neurotransmiter dan mempengaruhi proses perkembangan dalam sistem saraf pusat. Senyawa ini membantu pembentukan dopamin dan noradrenalin serta mengatur emosi dan belajar. Penurunan senyawa ini memicu peningkatan peroksinitrit yang terlibat dalam neuropatologi pada autisme. Disisi lain, NO juga mampu mengoksidasi $\mathrm{Fe}^{++}$hemoglobin eritrosit menjadi $\mathrm{Fe}^{+++}$sehingga terbentuk methemoglobin. Methemoglobin tidak mempunyai kemampuan mengikat oksigen dan peningkatan methemoglobin akan mengganggu transportasi oksigen menuju jaringan ${ }^{11}$. Aktifitas NO diukur secara tidak langsung melalui methemoglobin. ${ }^{6,7}$

Beberapa penelitian mengungkapkan bahwa pada autisme terjadi peningkatan peroksidasi lipid dan penurunan seruloplasmin dan transferin. ${ }^{4}$ Penelitian lain juga mengungkapkan bahwa pada autisme telah terjadi stres oksidatif yang dapat mempengaruhi membran eritrosis. ${ }^{6}$ Di Indonesia, penelitian autisme yang berkaitan dengan status oksidatif, jarang dilakukan. Oleh karena itu, pada penelitian ini dikaji status oksidatif pada autisme dengan menggunakan aktivitas katalase, kadar methemoglobin dan karbonil sebagai parameter. Hasil penelitian ini diharapkan dapat menjadi pijakan dalam membantu terapi autisme.

\section{Bahan dan cara}

Penelitian ini merupakan penelitian observational analitik yang dilakukan secara cross sectional. Sebanyak 39 pasien autisme yang berobat di Pusat Terapi Anak Manis Banjarmasin menjadi subyek penelitian, sedangkan sebagai kontrol adalah anak normal sebanyak 10 orang di Taman Sosialisasi Anak Bustanul Mảmur Banjarmasin. Penelitian dilakukan pada tahun 20032004 di Bagian Ilmu Kesehatan Anak Fakultas Kedokteran Universitas Lambung Mangkurat. Semua anak autisme dan kontrol telah didiagnosis oleh spesialis anak dan psikiater melalui riwayat perkembangan perilaku dan pemeriksaan klinis, serta menampakan gejala sesuai DSM-IV. Stres oksidatif diukur dengan menggunakan parameter aktivitas katalase, kadar methemoglobin, dan kadar senyawa karbonil.

\section{Pemeriksaan enzim katalase ${ }^{12}$}

Disiapkan dua tabung untuk larutan blanko dan larutan uji. Pada tabung blanko dimasukkan $1 \mathrm{ml}$ hemolisat dan $0,5 \mathrm{ml}$ dapar fosfat. Pada tabung uji dimasukkan $1 \mathrm{ml}$ hemolisat dan $0,5 \mathrm{ml} \mathrm{H}_{2} \mathrm{O}_{2}$. Dilakukan pengukuran serapan larutan blangko dan larutan uji pada $\mathrm{l}=240 \mathrm{~nm} .{ }^{10}$ Kedua serapan yang terukur adalah serapan pada $\mathrm{t}=0$ detik. Setelah 30 detik diukur kembali larutan blangko dan larutan uji. Serapan yang terukur disebut serapan pada $\mathrm{t}=30$ detik. Aktivitas katalase ditunjukkan oleh konstanta kecepatan reaksi (k) orde satu, yakni:

$$
\mathrm{k}=\ln \frac{\text { Abs saat } \mathrm{t}=0}{\text { Abs saat } \mathrm{t}=30} \times \frac{1}{\mathrm{t}_{2}-\mathrm{t}_{1}} \text { dengan } \mathrm{k} \text { dalam } \mathrm{dt}^{-1}
$$


Sari Pediatri, Vol. 7, No. 2, September 2005

\section{Pemeriksaan methemogobin ${ }^{13}$}

Dicampurkan 0,2 $\mathrm{ml}$ darah, $4 \mathrm{ml}$ buffer fosfat $\mathrm{pH}=6,8$ dan $6 \mathrm{ml}$ detergen non ionik. Selanjutnya, campuran dibagi ke dalam 2 tabung, yakni tabung A dan B. Tabung A dibedakan menjadi 2, yakni tabung uji dan blangko. Tabung A uji serapannya diukur pada $\mathrm{l}=630$ nm (D1) dan kemudian ditambahkan 1 tetes KCN kemudian diukur serapannya $\mathrm{l}=630 \mathrm{~nm}$ (D2). Tabung $\mathrm{B}$ uji berisi $\mathrm{K}_{3}\left[\mathrm{Fe}(\mathrm{CN})_{6}\right]$ dan diukur serapan $\mathrm{l}=630$ nm (D3) kemudian ditambahkan 1 tetes KCN dan diukur serapannya $\mathrm{l}=630 \mathrm{~nm}(\mathrm{D} 4)$.

Perhitungan kadar methemoglobin:

(D1-D2)

$$
\text { Meth-Hb }=\frac{(\mathrm{D} 1-\mathrm{D} 2)}{(\mathrm{D} 3-\mathrm{D} 4)} \times 100 \%
$$

\section{Pemeriksaan kadar senyawa karbonil}

Metoda pengukuran yang digunakan adalah metode DNPH (dinitro phenilhidrazin) yang dimodifikasi. ${ }^{14,15}$ Dari tiap larutan uji diambil sebanyak $0,5 \mathrm{ml}$ larutan. Kemudian setiap 0,5 ml larutan tersebut dibagi lagi menjadi 2 tabung dengan volume masing-masing 0,25 $\mathrm{ml}$. Tabung pertama adalah sampel (A) dan tabung kedua adalah blanko (B), sehingga akhirnya akan tersedia 8 tabung. Selanjutnya ke dalam setiap sampel (tabung A) ditambahkan DNPH sebanyak $1 \mathrm{ml}$, dan ke dalam blanko (tabung B) ditambahkan $1 \mathrm{ml} \mathrm{HCl}$ 2,5 M. Kemudian larutan-larutan tersebut diinkubasi selama 45 menit pada suhu ruang dan terlindung dari cahaya, dan dikocok dengan vortex tiap 15 menit.

Tahap selanjutnya menambahkan $1 \mathrm{ml}$ TCA (asam trikloroasetar) $20 \%$ ke dalam masing-masing tabung (A dan B), lalu diinkubasi di dalam es selama 5 menit. Sentrifugasi selama 5 menit dengan kecepatan 1400 $\mathrm{rpm}$, dan membuang supernatannya. Setelah itu dilakukan pencucian dengan menambahkan $1 \mathrm{ml}$ etanol-etil asetat ke dalam setiap tabung, sentrifugasi selama 5 menit pada kecepatan $1400 \mathrm{rpm}$, lalu membuang supernatannya. Pencucian diulangi sebanyak 3 kali. Tahap akhir dari pengukuran senyawa karbonil ini adalah dengan menambahkan $1 \mathrm{ml}$ urea $9 \mathrm{M}$, dan menginkubasi larutan pada suhu $37^{\circ} \mathrm{C}$ selama 10 menit sambil dikocok. Setelah itu larutan disentrifugasi dengan kecepatan $1400 \mathrm{rpm}$ selama 5 menit. Selanjutnya warna yang dihasilkan diukur serapannya pada panjang gelombang $390 \mathrm{~nm}$. Kerusakan protein dihitung dengan menggunakan persamaan $\mathrm{C}=\mathrm{A} /(\mathrm{eb})$

dengan keterangan $A=$ absorbansi, e= koefisien ekstingsi $22000 \mathrm{mM} \mathrm{cm}^{-1}$, dan $\mathrm{b}=1 \mathrm{~cm}$. Data yang diperoleh, kemudian dianalisis dengan uji student $t$ dengan nilai kemaknaan $\mathrm{p}<0,05$ menggunakan program SPSS for windows versi 10.

\section{Hasil}

Parameter stres oksidatif akibat autisme dapat dilihat pada Tabel 1, 39 anak autisme terdiri dari tujuh anak laki-laki dan 32 anak perempuan, rerata usia 3,8 bulan. Kelompok kontrol terdiri dari tiga anak laki-laki dan tujuh anak perempuan, rerata usia 3,8 bulan pada anak laki-laki dan 3,6 pada anak perempuan.

Tabel 1. Karakteristik subyek

\begin{tabular}{lll}
\hline Karakteristik & Autisme & Kontrol \\
\hline Jumlah subyek (n) & 39 & 10 \\
Laki-laki/perempuan & $7 / 32$ & $3 / 7$ \\
Rerata Usia (tahun) & 3,8 & 3,6 \\
\hline
\end{tabular}

Tabel 2 memperlihatkan rerata aktifitas katalase pada autisme $0,0061 \pm 0,0013 \mathrm{~s}^{-1}$, sedangkan kontrol adalah $0,0086 \pm 0,0042 \mathrm{~s}^{-1}$. Rerata hasil pengukuran methemoglobin pada autisme adalah $30,38 \pm 15,44 \%$ sedangkan kelompok kontrol 21,73 $\pm 9,66 \%$. Kadar senyawa karbonil pada autisme adalah $0,411 \pm 337693$ $\mathrm{iM} \mathrm{ml}{ }^{-1} / \mathrm{gr}$ dan kontrol 0,424 $\pm 265861 \mathrm{iM} \mathrm{ml}{ }^{-1} / \mathrm{gr}$. Ujit untuk dua rata-rata pada $a=5 \%$ menyimpulkan aktivitas katalase dan kadar methemoglobin berbeda secara bermakna dibandingkan kontrol $(\mathrm{P}<0,05)$,

Tabel 2. Parameter stres oksidatif

\begin{tabular}{llll}
\hline Parameter & Autisme & Kontrol & $\mathrm{p}$ \\
\hline Aktivitas katalase $\left(10^{-3} \mathrm{~s}^{-1}\right)$ & $6,2 \pm 1,3$ & $8,7 \pm 4,2$ & $\mathrm{p}<0,05$ \\
Methemoglobin $(\%)$ & $30,4 \pm 5,4$ & $21,7 \pm 9,6$ & $\mathrm{p}<0,05$ \\
Kadar karbonil $\left(\mathrm{iM} \mathrm{m} \mathrm{m}^{-1} / \mathrm{gr}\right)$ & $0,4 \pm 0,1$ & $0,4 \pm 0,1$ & $\mathrm{p}>0,05$ \\
\hline
\end{tabular}


sedangkan kadar senyawa karbonil kelompok risiko dan kontrol tidak berbeda $(P>0,05)$

\section{Pembahasan}

Katalase tergolong kelas enzim oksidoreduktase, yaitu kelas enzim yang mengkatalisis reaksi oksidasi reduksi. Katalase berperan dalam pemecahan senyawa $\mathrm{H}_{2} \mathrm{O}_{2}$ menjadi $\mathrm{H}_{2} \mathrm{O}$ dan $\mathrm{O}_{2}$. Katalase banyak ditemukan pada sel darah merah, sitoplasma, mitokondria, dan peroksisom berbagai sel. Katalase merupakan enzim homotetramer yang menggunakan Fe sebagai kofaktor. Enzim ini disandi oleh gen pada kromosom 11. Apabila terjadi mutasi pada gen ini, akan terjadi akatalasemia. Pasien akatalasemia menunjukkan aktivitas katalase yang rendah pada sel darah merah dan berbagai jaringan namun kelihatan dapat hidup normal. ${ }^{16,17}$

Pada penelitian ini akivitas katalase anak autisme lebih rendah dari normal secara bermakna. Aktivitas katalase yang rendah menunjukkan adanya penumpukan $\mathrm{H}_{2} \mathrm{O}_{2}$ (sebagai SOR), yang berakibat pada oksidasi gugus $-\mathrm{SH}$ dari protein dan peroksidasi lipid pada membran sel. ${ }^{18,19}$ Kemampuan $\mathrm{H}_{2} \mathrm{O}_{2}$ dalam oksidasi biomolekul disebabkan oleh sifat yang dimilikinya, yakni larut dalam molekul lemak dan mampu menembus membran. ${ }^{7}$ Kemampuan tersebut menyebabkan $\mathrm{H}_{2} \mathrm{O}_{2}$ bereaksi pada jarak yang cukup jauh dari tempat pembentukannya, ${ }^{20}$ sehingga potensial menimbulkan kerusakan pada susunan saraf pusat. Selain itu, mielin sel saraf kaya asam lemak tak jenuh sehingga peka terhadap kerusakan oksidatif. ${ }^{21}$ Hasil penelitian ini sesuai dengan penelitian Sogut, yakni kadar GSH-Px (Glutathion Peroksidase) plasma lebih tinggi, yang mengindikasikan kadar $\mathrm{H}_{2} \mathrm{O}_{2}$ di dalam sel darah merah meningkat. ${ }^{7}$

Selain akivitas katalase, kadar NO pada autisme ditemukan lebih tinggi daripada anak normal yang ditandai oleh lebih tingginya kadar methemoglobin pada autisme. Nitrit oksid (NO) disintesis dari asam amino arginin dengan enzim nitric oxide synthase sebagai katalisator. Gugus thiol $(-\mathrm{SH})$ enzim adalah target penyerangan $\mathrm{NO}^{6,7}$

Toksisitas senyawa NO diketahui jika bereaksi dengan $\mathrm{O}_{2}$ yang membentuk peroksinitirt. Peroksinitrit menyebabkan peroksida lipid, nitrosilasi beberapa molekul dan inaktivasi sodium channel. Hasil penelitian menunjukkan peningkatan kadar peroksinitrit melalui peningkatan methemoglobin pada autisme dibandingkan kontrol. Peningkatan kadar NO dapat menyebabkan neurodestruktif, sehingga NO diduga berperan dalam patogenesis terjadinya autisme. Hasil penelitian ini sesuai dengan hasil penelitian Zoroglu dan Sogut, yang menyimpulkan terjadi peningkatan bermakna kadar NO pada autisme. ${ }^{6,7}$

Aktivitas katalase yang lebih rendah dan kadar methemogobin yang lebih tinggi belum menyebabkan kerusakan oksidatif pada protein yang ditandai dengan rendahnya kadar karbonil sebagai indikator kerusakan protein. Hal ini diduga adanya kemampuan sinergis dari antioksidan yang berasal dari dalam maupun luar tubuh. Meskipun demikian, penelitian Sogut menyimpulkan adanya kerusakan oksidatif pada kasus autisme, berupa peningkatan peroksidasi lipid. ${ }^{7}$

Hasil penelitian menyimpulkan bahwa terdapat perbedaan bermakna antara aktivitas katalase dan kadar methemoglobin pada autisme dan tidak ada perbedaan

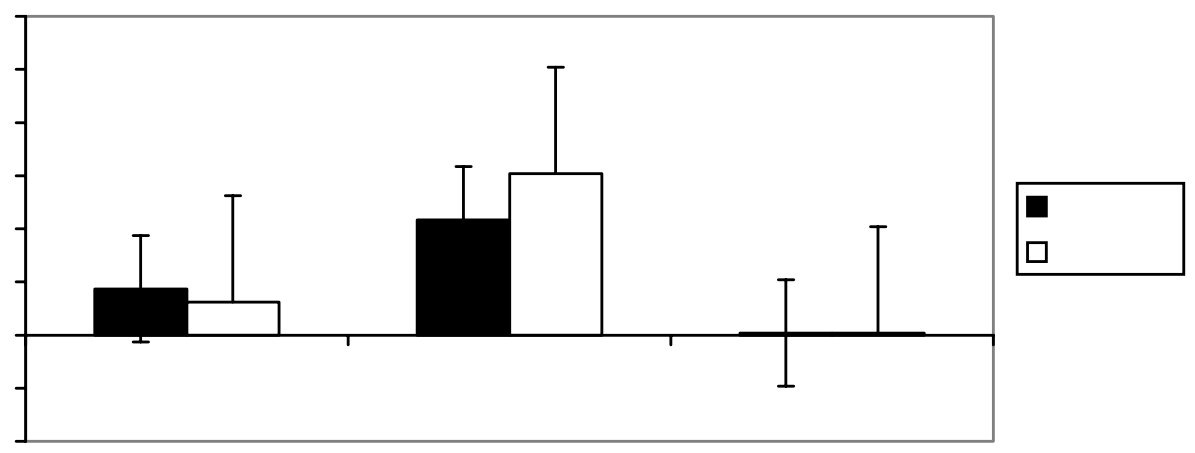

Gambar 1. Parameter stres oksidatif pada autisme. 
kadar senyawa karbonil dalam darah autisme dan anak normal. Oleh karena itu, untuk mencegah kerusakan lebih lanjut perlu dipertimbangkan pemberian antioksidan eksogen pada anak autisme.

\section{Kesimpulan}

Kesimpulan penelitian ini adalah aktivitas katalase pada anak autisme lebih rendah sedangkan kadar methemoglobin lebih tinggi secara bermakna daripada anak normal. Meskipun demikian, keadaan tersebut belum sampai mempengaruhi kerusakan oksidatif protein. Perlu dilakukan penelitian lebih lanjut untuk mengetahui aktivitas antioksidan endogen lainnya seperti superoksida dismutase dan glutation peroksidase dan untuk mengetahui apakah kadar senyawa anti oksidan berhubungan dengan berat ringannya anak autisme secara klinis.

\section{Daftar Pustaka}

1. Widodo Dwi P. Perkembangan bicara anak. Diajukan pada Seminar di Jakarta, 16 juni 2001

2. Intan T, Idjal. Autism. Journal of Health Science Fatmawati. 2001; 3: 381-4

3. Pusponegoro, H D. Penyebab dan terapi medis autisme. Diajukan pada Seminar Gangguan Perkembangan Anak (Autisme), 8 April 2000, Jakarta. Jakarta : Andika Bangun Cipta Dinamika Proaktif, 2000

4. Chauhan A, Chauhan V, Browm T, Cohen I. Oxidative Stress in Autism: increased lipid peroxidation and reduced serum levels of ceruloplasmin and transferin-the antioxidant proteins. Dikutip dari http://www. sciencedirect.com diakses tanggal 10 Maret 2005.

5. Edelson. Autistic Spectrun Disorder: neurotoxicity caused by environmental toxin. Dikutip dari http:// www.edelson.com/autism/paper 1 pdf, diakses tanggal 10 Maret 2005.

6. Zoroglu SS, Armutcu F, Ozen Z, Gurel A, Sivasli, Yetkin O. Increased oxidative stress and altered activities of erythrocyte free radical scavenging in autism. Eur Arch Psychitary and Clin. Neurosci. 2004; 254:143-7.

7. Sogut S, Zoroglu SS, Ozyurt H, Yilmaz HR, Ozugurlu F, Sivasli E. et al. Change in nitric oxide levels and antioxidant enzyme activities may have a role in the pathophysiological mechanisms involved in autism. Clin Chim Acta 2003; 331:111-7.
8. Suhartono E. Senyawa oksigen reaktif serta potensi antioksidan sumber daya kelautan dan perikanan. Diajukan pada Seminar Nasional Pemanfaatan Potensi Sumber Daya Alam dalam Meningkatkan derajat Kesehatan Masyarakat Menuju Indonesia Sehat 2010. Banjarbaru 12 Oktober, 2003.

9. Kirkman, Henry N, Rolfo M, Ferarris AM, Gaetani GF. Mechanism of protection of catalase by NADPH: kinetics and stoichiometry. J Biol Chem, 1999; 274: 13908-14.

10. Halliwell B, Whiteman M. Measuring reactive oxygen species and oxidative damage in vivo and cell culture: how you should do it and what do the results mean? $\mathrm{Br}$ J Pharm 2004; 142:231-55.

11. Speakman ED, Boyd JC, Burns DE. Measurement hemoglobin in neonatal sample containing fetal hemoglobin. Clin. Chem. 1995; 41:458-61.

12. Koracevic.D, Koracevic.G, Djordjevic, Andrejevic, Cosic. Method for the measurement of antioxidant activity in human body, J Clin Pathol. 2001:54:356-61.

13. Tarpey MM, Fridovich I. Methods of detection of vascular reactive species: nitric oxide, superoxide, hydrogen peroxide, and peroxinitrite. Circ. Res. 2001; 89:22436.

14. Uchida K, Kanematsu M, Sakai K, Matsuda T, Hattori Dan, Mizuno Y, et al. Protein bound acrolein: potential markers for oxidative stress. Proc. Natl. Acad. Sci. USA 1998; 95:4882-7.

15. Sadikin M. Pelacakan dampak radikal bebas terhadap biomolekul. Kursus Penyegar Biokimia. Jakarta: Fakultas Kedokteran Indonesia, 2000

16. Mark DB, Mark AD, Smith IM. Biokimia kedokteran dasar: sebuah pendekatan klinis. Jakarta:EGC, 2000.

17. Mate, JM. Mutants that alter the covalent structure catalase hydroperoxidase II from Escherichia coli. J BiolChem.1999.

18. Suhartono E, Fujiati, Panghiyangani R. Pengaruh vitamin C terhadap jumlah eritrosit dan kadar hemoglobin pada tikus galur Sprague Dawley yang dipajan sinar ultraviolet. J Ked YARSI 2002; 12:42-5.

19. Gitawati R. Radikal bebas-sifat dan peran dalam menimbulkan kerusakan/ kematian sel. Cermin Dunia Kedokteran 1995: 33-5.

20. Halliwell B, Gutteridge JMC. Free radicals in biology and medicine. Edisi ketiga. New York: Oxford University Press, 1999.

21. Singh RP, Sharad S, Kapur S. Free radicals and stress in neurodegenerative diseases: relevance of dietary antioxidants. JIACM 2004; 5: 2118-25. 